\title{
Assessment of chronic ankle instability
}

\author{
Kathryn M Refshauge ${ }^{*}$, Claire E Hiller \\ From 3rd Congress of the International Foot and Ankle Biomechanics Community \\ Sydney, Australia. 11-13 April 2012
}

Chronic ankle instability is a complex problem which often follows ankle sprain. This workshop will discuss the latest models of chronic ankle instability and give an overview of the latest research in the area. Assessment tools available in the clinic as well as the laboratory setting will be demonstrated in the workshop with the opportunity for participants to practice. Assessments covered will include; balance, strength, joint laxity, motor control, and proprioception.

Published: 10 April 2012

\section{References}

1. Arnold BL, De La Motte $S$, Linens $S$, et al: Ankle instability is associated with balance impairments: a meta-analysis. Med Sci Sports Exerc 2009, 41:1048-1062.

2. Delahunt E, Coughlin G, Caulfield B, et al: Inclusion criteria when investigating insufficiencies in chronic ankle instability. Med Sci Sports Exerc 2010, 42:2106-2121

3. Hertel J: Functional anatomy, pathomechanics, and pathophysiology of lateral ankle instability. J Athl Train 2002, 37:364-375.

4. Hiller CE, Kilbreath SL, Refshauge KM: Chronic ankle instability: evolution of the model. J Athl Train 2011, 46:133-141.

5. Hiller CE, Nightingale EJ, Lin CW, et al: Characteristics of People with Recurrent Sprains: A systematic review with Meta-analysis. Br J Sports Med 2011, 45:660-672.

6. Munn J, Sullivan SJ, Schneiders AG: Evidence of sensorimotor deficits in functional ankle instability: a systematic review with meta-analysis. J Sci Med Sport 2010, 13:2-12.

7. Wikstrom EA, Naik S, Lodha $N$, et al: Balance capabilities after lateral ankle trauma and intervention: a meta-analysis. Med Sci Sports Exerc 2009, 41:1287-1295.

Submit your next manuscript to BioMed Central and take full advantage of:

- Convenient online submission

- Thorough peer review

- No space constraints or color figure charges

- Immediate publication on acceptance

- Inclusion in PubMed, CAS, Scopus and Google Scholar

- Research which is freely available for redistribution

\section{() Biomed Central}

